Check for updates

Cite this: Mater. Adv., 2022, 3,3165

Received 2nd November 2021, Accepted 14th February 2022

DOI: 10.1039/d1ma01021b

rsc.li/materials-advances

\title{
Porous organic polymer (POP) nanosheets: an efficient photo-catalyst for visible-light assisted $\mathrm{CO}_{2}$ reduction $\dagger$
}

\author{
Surya Das, ${ }^{a}$ Ipsita Hazra Chowdhury, ${ }^{a}$ Adwitiya Chakraborty, ${ }^{b}$ \\ Milan Kanti Naskar, (iD b Mitali Sarkar ${ }^{\mathrm{a}}$ and S. K. Manirul Islam (D) *a
}

\begin{abstract}
We have designed a nano-sheet-like porous organic polymer (POP) constructed via a schematic hydrothermal process and characterized it using PXRD, $\mathrm{N}_{2}$ adsorption-desorption studies, UV-vis, XPS and microscopic analyses (TEM and FESEM). The synthesized POP can perform as a dynamic photo-catalyst for the production of formic acid and formaldehyde. This pure polymeric porous photo-catalytic system demonstrates exceptionally good catalytic performances for the generation of formic acid (major product) and formaldehyde (minor product) with TON values of 355 and 47, respectively, under visible light irradiation. The as-synthesized catalyst also exhibited excellent yield for the synthesis of both products $\mathrm{HCOOH}$ (TON: 338) and $\mathrm{HCHO}$ (TON: 10) even under sunlight irradiation. The recyclability of the photocatalyst is also confirmed for five reaction cycles and the POP material showed excellent recycling capability without any visible catalyst degradation.
\end{abstract}

\section{Introduction}

Fossil fuels have been the backbone of modern industrial development since the industrial revolution. For advanced technology in industry, the combustion of fossil fuels generates carbon dioxide $\left(\mathrm{CO}_{2}\right)$, which is one of the most important greenhouse gases contributing to a sharp increase in global temperature. According to the National Oceanic and Atmospheric Administration (NOAA), the mean concentration of $\mathrm{CO}_{2}$ in the atmosphere increased to $419.05 \mathrm{ppm}$ in April 2021. ${ }^{1}$ The advancement of $\mathrm{CO}_{2}$ emissions control and carbon capture processes will mitigate the unusual changes seen in global climate. Because $\mathrm{CO}_{2}$ is the chief greenhouse gas, its capture and catalytic transformation is believed to be a serious matter to solve at present. Given the thermally stable and inert nature of $\mathrm{CO}_{2}$, it is extremely beneficial to construct advanced catalysts to facilitate the conversion of $\mathrm{CO}_{2}$ to other higher value-added chemicals under mild conditions. Due to the most highly oxidized form of carbon, $\mathrm{CO}_{2}$ is thermodynamically stable and/or kinetically inert. ${ }^{2}$ Therefore, utilization of $\mathrm{CO}_{2}$ is still a challenging issue and a major thriving area of research

\footnotetext{
${ }^{a}$ Department of Chemistry, University of Kalyani, Kalyani, Nadia 741235 , West Bengal, India. E-mail: manir65@rediffmail.com; Fax: +91-33-2582-8282; Tel: +91-33-2582-8750

${ }^{b}$ Advanced Ceramics \& Composites Division, CSIR-Central Glass and Ceramic Research Institute, Kolkata 700 032, West Bengal, India

$\dagger$ Electronic supplementary information (ESI) available. See DOI: 10.1039/ d1ma01021b
}

to solve the environmental problem. However, $\mathrm{CO}_{2}$ is a nontoxic, renewable, inexpensive and abundant raw $\mathrm{C} 1$ feedstock and it is a C1 building block for the synthesis of various valuable chemicals with added economic value such as carbonate, carbamate, urea, etc. ${ }^{3-8}$ Furthermore, through $\mathrm{CO}_{2}$ reduction some $\mathrm{C} 1$ chemicals such as $\mathrm{HCHO}, \mathrm{HCOOH}, \mathrm{CH}_{4}$, $\mathrm{CO}$, and $\mathrm{CH}_{3} \mathrm{OH}$ can easily be formed through thermo-catalysis, electrocatalysis and photocatalysis methods. ${ }^{9}$ Recently, to maintain the ecological balance of the earth, photocatalytic reduction ${ }^{10}$ of $\mathrm{CO}_{2}$ has become a more efficient and greener approach to convert atmospheric $\mathrm{CO}_{2}$ into eco-friendly fuels and organic materials in a sustainable and cost-effective manner which provides a way to obtain carbon resources. ${ }^{11}$ To avert the adverse effects of global warming, a large-scale study has been dedicated to the development of $\mathrm{CO}_{2}$-philic adsorbent materials that are robust, have significantly high chemical/ mechanical stability, and are regeneration efficient and economically inexpensive. ${ }^{12}$

Due to their great performance and wide application, a novel kind of emerging nanoporous material has drawn tremendous interest in the fields of gas storage, gas separation, energy conversion, medicine loading and delivery, energy storage, catalysis, and so on. ${ }^{13-16}$ As a class of emerging photocatalysts, organic conjugated polymers offer high flexibility in tuning the framework of the backbone and porosity to fulfill the requirements for photocatalytic applications. ${ }^{17}$ In this consideration, highly crosslinked porous organic polymers (POPs), ${ }^{18-21}$ with greater thermal and chemical stabilities, ${ }^{22}$ inherent nanoscale 
porosity $^{23}$ large surface areas ${ }^{24}$ and diverse building blocks are consummate platforms for the creation of heterogeneous catalysts for $\mathrm{CO}_{2}$ conversion. Here, we mainly focus on photocatalytic applications of POPs particularly for $\mathrm{CO}_{2}$ reduction.

In the past few years, the work on the reduction of $\mathrm{CO}_{2}$ into formic acid ( $\mathrm{HCOOH}$ ) and/or formaldehyde (HCHO) using covalent organic framework (COF) and metal oxide has been established photo-catalytically. Our recent work consisted of metal free PCA-TOL (4,4'-biphenyldicarbaldehyde-orthotolidine) POP with strong crystallinity and robust stability for heterogeneous photocatalytic reduction of $\mathrm{CO}_{2}$ into both formic acid $(\mathrm{HCOOH})$ and formaldehyde ( $\mathrm{HCHO})$ under visible light in the presence of acetonitrile $\left(\mathrm{CH}_{3} \mathrm{CN}\right)$ solvent. The reduced products of $\mathrm{HCHO}$ and $\mathrm{HCOOH}$ are widely abundant feedstocks in the chemical industry and find various valuable applications. HCHO is used in hydrogen fuel cells for hydrogen gas production. It serves as a liquid organic hydrogen carrier molecule (LOHC) ${ }^{25}$ and useful life product whereas $\mathrm{HCOOH}$ (the two-electron reduced products of $\left.\mathrm{CO}_{2}\right)^{26}$ is used as an interesting fuel in fuel cells, a hydrogen storage material and a reducing agent for many organic reactions. ${ }^{27}$

\section{Experimental}

\section{Preparation of the catalyst}

The synthesis of the PCA-TOL porous organic polymer (POP) material is delineated in Scheme 1.

\section{Synthetic procedure of the PCA-TOL porous organic polymer} (POP) material

PCA-TOL POP was fabricated by the reaction of $4,4^{\prime}$-biphenyldicarbaldehyde (PCA) and ortho-tolidine (TOL) using para-toluene sulfonic acid (PTSA) in a hydro-thermal process as shown in Scheme 1. A mixture of $7.5 \mathrm{mmol}$ PTSA and $1.35 \mathrm{mmol}$ TOL was taken in a mortar-pestle and homogeneously mixed for 10 minutes to obtain a grey color glue-like material. $0.9 \mathrm{mmol}$ PCA was added to it subsequently with appropriate grinding for the subsequent 10-15 minutes. A small amount of distilled water $(100-200 \mu \mathrm{L})$ was

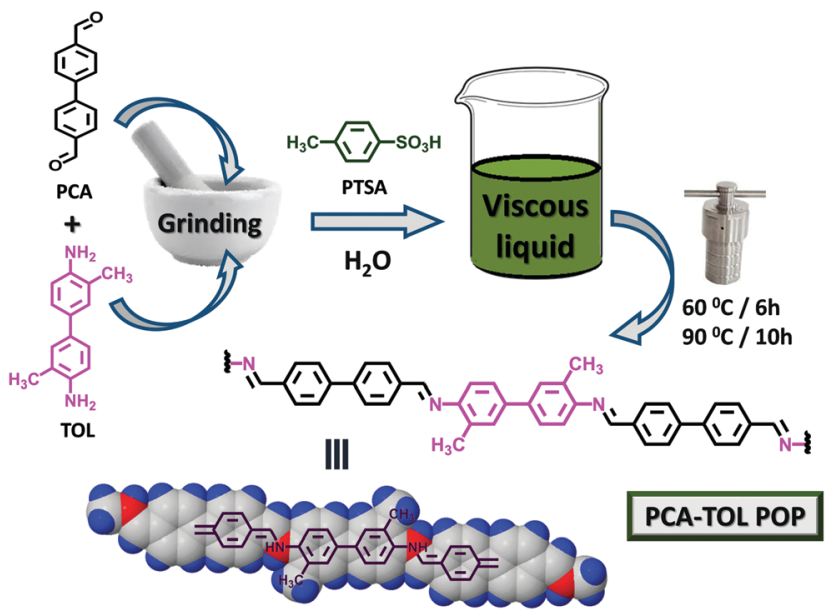

Scheme 1 Synthetic route of the PCA-TOL POP nano-sheet. added drop-wise to form a viscous paste, and it was put into a Teflon-lined steel autoclave and heated at $60^{\circ} \mathrm{C}$ for the first $6 \mathrm{~h}$ and then at $90{ }^{\circ} \mathrm{C}$ for the next $10 \mathrm{~h}$ under stable conditions. Afterward, $\mathrm{N}, \mathrm{N}$-dimethyl acetamide (DMAc) and excess acetone were used to wash the PCA-TOL POP product until it was available in pure form. The POP material was dried under vacuum at room temperature to obtain the green colored PCA-TOL POP (80\% isolated yield).

\section{General procedure for the synthesis of formic acid and formaldehyde using PCA-TOL POP}

The procedure of formic acid and formaldehyde synthesis from atmospheric $\mathrm{CO}_{2}$ was performed at room temperature for 6 hours using $5 \mathrm{mg}$ of PCA-TOL POP as a heterogeneous catalyst, $5 \mathrm{mg}$ of nickel chloride $\left(\mathrm{NiCl}_{2}\right)$ as a co-catalyst and $1 \mathrm{mmol}$ triethanolamine (TEOA) as a sacrificial electron donor in the presence of $5 \mathrm{~mL}$ of acetonitrile $\left(\mathrm{CH}_{3} \mathrm{CN}\right)$ solvent in a round bottom flask using $445 \mathrm{~nm}$ blue LED light irradiation. After cooling the reaction mixture at the end, the catalyst was isolated using a filtration method and the product was confirmed using a UV-Visible spectrophotometer and also analyzed via ${ }^{1} \mathrm{H}$ and ${ }^{13} \mathrm{C}$ NMR spectroscopy (ESI $\dagger$ ).

\section{Results and discussion}

\section{Characterization}

The PCA-TOL POP formation was confirmed using powder diffraction analysis (Fig. 1). The presence of sharp peaks for the porous polymeric material implies the crystalline character of PCA-TOL POP. The crystallite size of PCA-TOL POP was calculated by Scherrer's equation as shown below:

$$
D=\kappa \lambda / \beta \cos \theta,
$$

where $\kappa$ (the shape factor) $=0.9$ (spherical particle), $\lambda$ (X-ray wavelength $)=0.15406 \mathrm{~nm}, \beta=$ FWHM and $\theta$ (the Bragg angle) $=$ $21.25 / 2=10.625$.

The particle size was found to be $7.97 \mathrm{~nm}$.

The FT-IR analysis spectra of the PCA-TOL POP catalyst are depicted in Fig. 2. The absorption band at $2920 \mathrm{~cm}^{-1}$ signifies

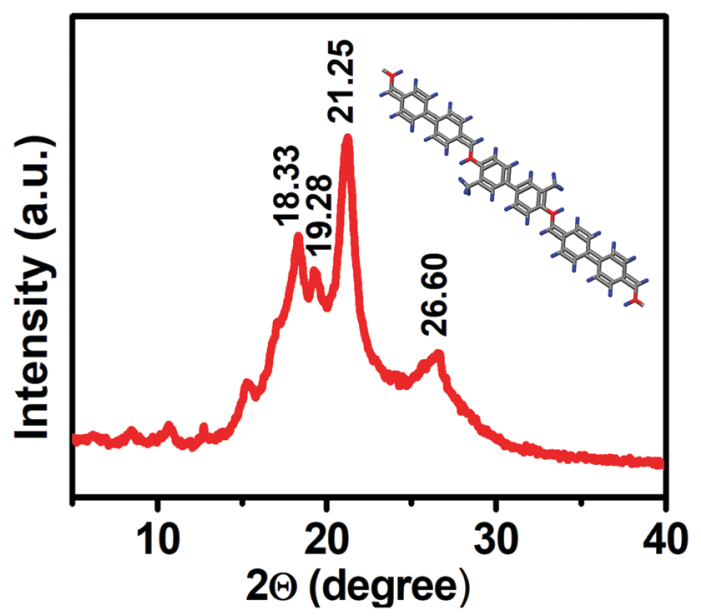

Fig. 1 Powder XRD patterns of PCA-TOL POP 


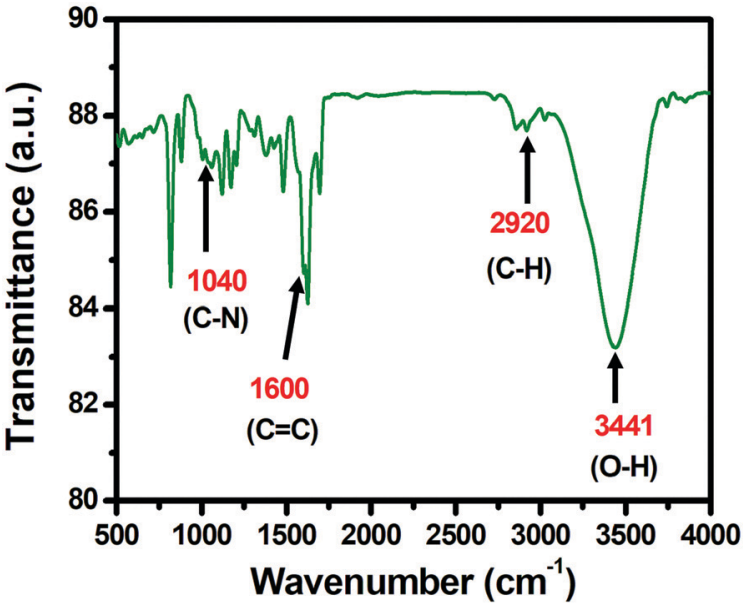

Fig. 2 FTIR spectra of PCA-TOL POP

the presence of the $\mathrm{sp}^{3}$ bond of carbon-hydrogen in the porous polymeric material PCA-TOL POP. The presence of the $\mathrm{C}=\mathrm{C}$ bonds in the aromatic rings was confirmed by the appearance of a sharp peak at $1600 \mathrm{~cm}^{-1}$ (stretching frequency). A peak appeared at $1040 \mathrm{~cm}^{-1}$ that corresponds to the $\mathrm{C}-\mathrm{N}$ stretching vibration. The broad peak at $3441 \mathrm{~cm}^{-1}$ appeared from the $\mathrm{O}-\mathrm{H}$ stretching vibration of the adsorbed water.

The thermal stability of the photocatalyst was studied via thermal gravimetric analysis of PCA-TOL POP executed at a rate of $10{ }^{\circ} \mathrm{C}$ temperature ramp/minute in air. Fig. 3 depicts the TG/DTA profile of the PCA-TOL POP catalyst. Due to burning of the residual portion and degradation of the POP framework, the reduction in mass begins at around $550{ }^{\circ} \mathrm{C}$ (Fig. 10). The exothermic peaks at $576{ }^{\circ} \mathrm{C}$ and $644{ }^{\circ} \mathrm{C}$ suggest the oxidative destruction of the organic matrix.

The $\mathrm{N}_{2}$ adsorption-desorption study of the POP photocatalyst is depicted in Fig. 4. It shows a type III isotherm with a H3 loop which indicates the presence of slit-like pores with nonuniform size and/or shape. The subsequent pore size

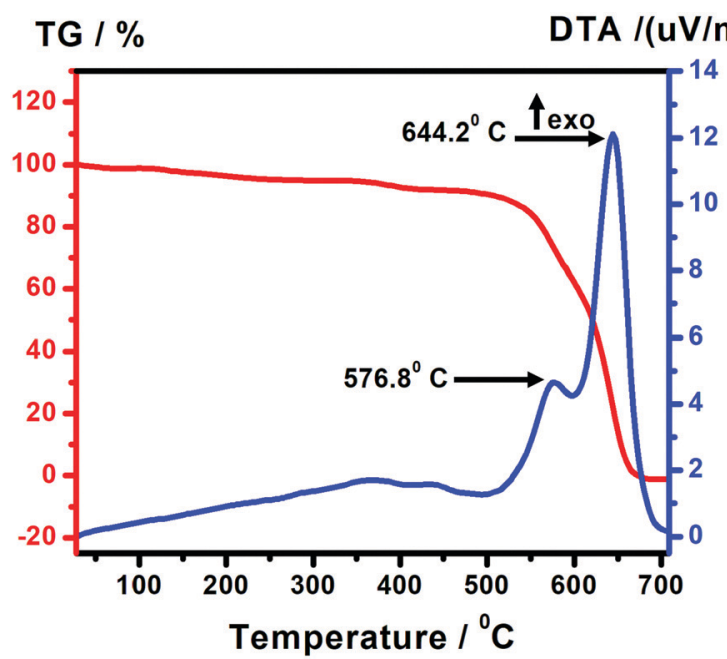

Fig. 3 TGA-DTA profile plot of PCA-TOL POP

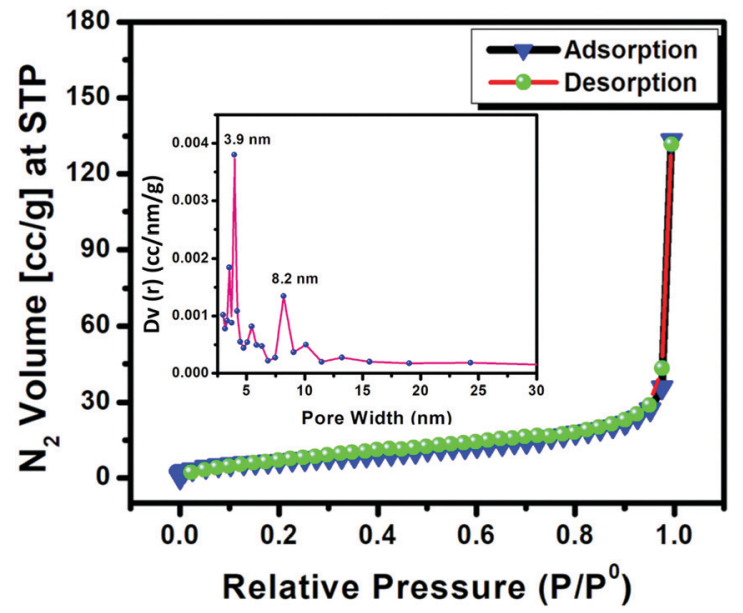

Fig. $4 \quad \mathrm{~N}_{2}$ adsorption-desorption isotherm of the POP material. The pore size distribution is shown in the inset.

distribution (PSD) resulting from the respective adsorption data is given in the inset of the isotherm plot, which confirms the presence of pores with irregular shape and size in the sample. The POP catalyst contains pores with a diameter range of about $2.5 \mathrm{~nm}$ to $10 \mathrm{~nm}$, which falls in the mesoporous region $(2-50 \mathrm{~nm})$. The mesoporous slit-like pores were generated from the interparticle pores among aggregated sheet-like particles. The estimated BET surface area and total pore volume of the POP catalyst are found to be $80.64 \mathrm{~m}^{2} \mathrm{~g}^{-1}$ and $0.43 \mathrm{~cm}^{3} \mathrm{~g}^{-1}$, respectively.

The nano-sheet-like structure of the PCA-TOL POP material is observed in the FESEM images (Fig. 5) which is further established by the HR-TEM images (Fig. 6). The crystalline organic nanosheets formed via strong interactions can be obtained using a reaction induced self-assembly approach. ${ }^{28}$ The porosity in the catalyst can be also observed in the HR-TEM images shown in Fig. 6b, c and e. Fig. 6f indicates the EDS analysis revealing the atomic percentages of carbon, nitrogen and oxygen as $85.9 \%, 2.3 \%$ and $11.8 \%$, respectively, in the sample. The sheet-like structure can be further observed from the atomic force microscopy (AFM) image (Fig. $6 \mathrm{~g}$ and $\mathrm{h}$ ). The corresponding height profiles reflected that the average thickness of the nanosheets is $\sim 70.0 \mathrm{~nm}$ (Fig. 6i).

The UV-Visible absorbance spectra (solid state) of the synthesized POP catalyst were recorded using barium sulphate as a reflecting substance. The presence of the broad absorption

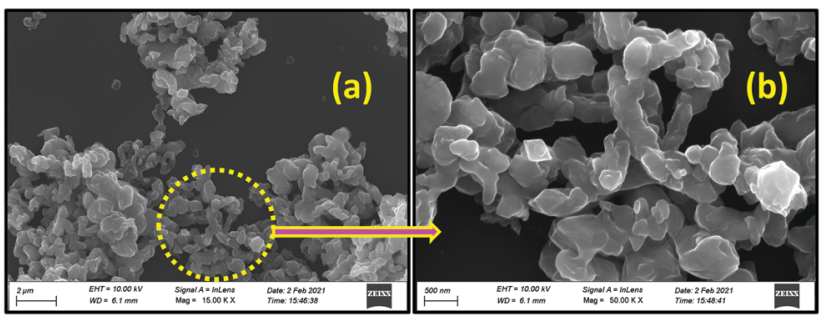

Fig. 5 FESEM images of the POP material at two different scales (a) $2 \mu \mathrm{m}$ and (b) $500 \mathrm{~nm}$. 


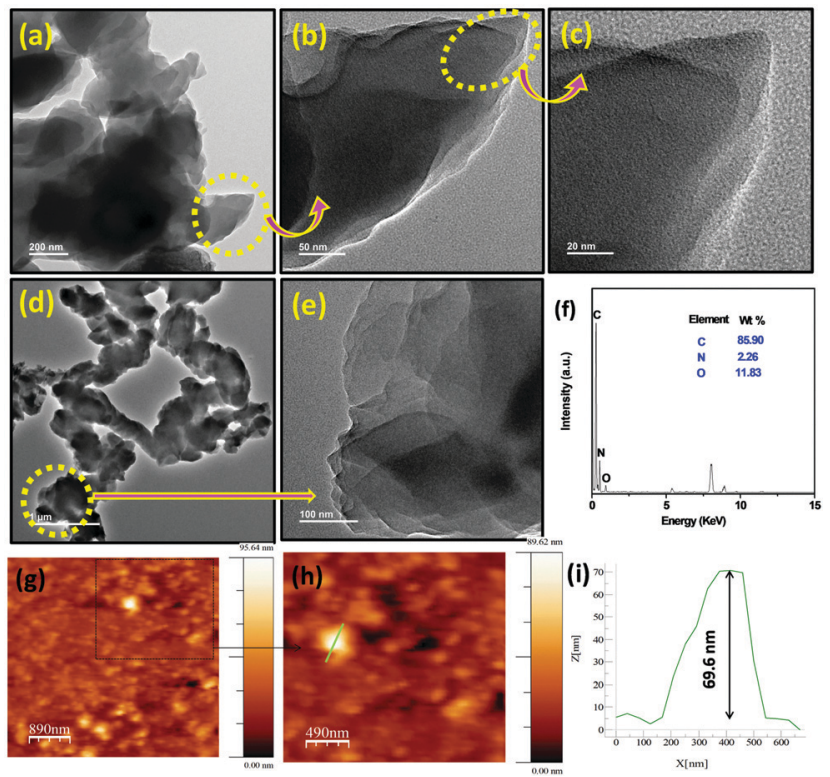

Fig. 6 HR-TEM images of PCA-TOL POP (a-e) at three different scales, (f) EDAX spectra and (g-i) AFM images of PCA-TOL POP.

spectra confirmed multiple transitions in the extremely wellordered conjugation arrangement in the material. As shown in Fig. 7a, the peak of POP in the UV-vis region suggests transitions of $\sigma$ to $\sigma^{*}$ and $\pi$ to $\pi^{*}$ attributed to the aromatic cycles. The fabricated POP shows an absorption edge at about $515 \mathrm{~nm}$ signifying the absorption of light in both the ultra-violet and visible regions. The band gap energy $\left(E_{\mathrm{g}}\right)$ is calculated using the following Tauc equation:

$$
(\alpha h \nu)^{1 / n}=A\left(h \nu-E_{\mathrm{g}}\right)
$$

where $\alpha, h \nu$, and $A$ are the absorption coefficient, energy of the photons and proportionality constant, respectively, according
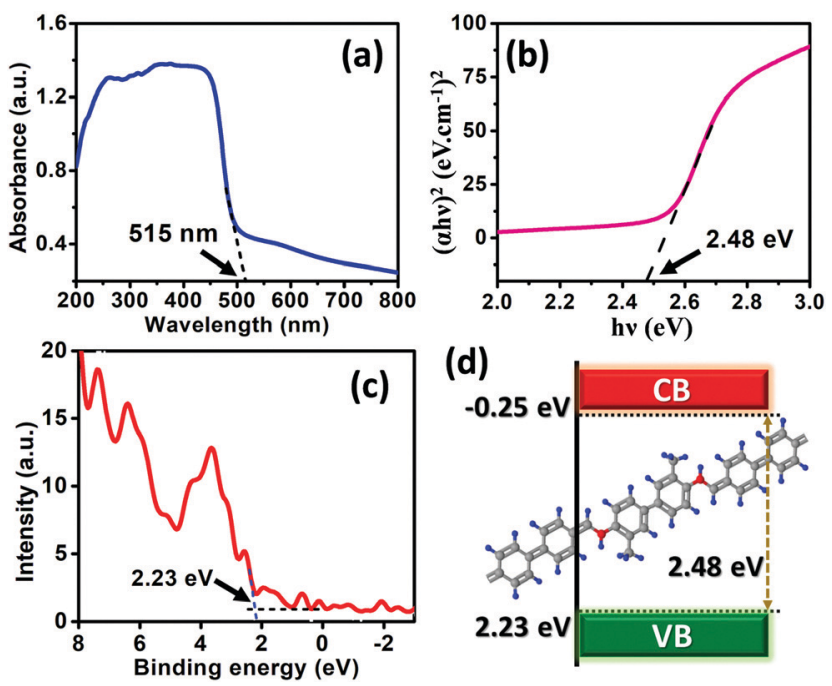

Fig. 7 (a) UV-Visible absorbance spectra and (b) Tauc plot for the absorption spectra. (c) XPS valence band spectra and (d) schematic diagram of the band structure of the POP sample. to the possibility of transition. The value constant, $n=2,1 / 2$, 3 and $3 / 2$ corresponds to transition patterns of indirect allowed, direct allowed, indirect forbidden and direct forbidden, respectively. In this context $n=1 / 2$ signifies direct allowed band gap. Here, the $(\alpha h \nu)^{2} v s$. $\mathrm{h} v$ curve for the POP material is depicted in Fig. $7 \mathrm{~b}$. The value of band gap energy $\left(E_{\mathrm{g}}\right)$ is observed to be $2.48 \mathrm{eV}$ which is calculated from the tangent extrapolated to the $X$-axis, signifying that the migration of electrons takes place between the valence band and the conduction band due to irradiation under visible light. Hence, the as-prepared POP could serve as a new potential applicant for a metal free photocatalytic reaction under visible-light irradiation. Fig. 7c shows the XPS valence band spectra of the POP catalyst from which the valence band energy (VB) is calculated to be $2.23 \mathrm{eV}$. The schematic diagram of the band structure of the synthesized POP photocatalyst is shown in Fig. 7d which was obtained from the experimental results. The conduction band energy (CB) was found to be $-0.25 \mathrm{eV}$.

The XPS survey (Fig. 8a) scan confirms that the carbon (C) and nitrogen $(\mathrm{N})$ exists within the synthesized catalyst. The XPS spectrum (high-resolution) of the $\mathrm{C}$ 1s region (Fig. 8b) on deconvolution illustrates peaks at binding energies of 284.8 and $285.5 \mathrm{eV}$, respectively indicating the presence of $\mathrm{C}-\mathrm{C} / \mathrm{C}=\mathrm{C} /$ $\mathrm{C}-\mathrm{H}$ and $\mathrm{C}-\mathrm{N} / \mathrm{C}=\mathrm{N}$ bonds in the catalyst. ${ }^{29}$ The $\mathrm{N} 1 \mathrm{~s}$ band (Fig. 8c) present at $398.8 \mathrm{eV}$ might be associated with the presence of the nitrogen atoms of the amino groups of the POP. The $\mathrm{O} 1 \mathrm{~s}$ band at $531.5 \mathrm{eV}$ (Fig. 8a) validates the presence of the surface adsorbed oxygen atoms within the synthesized catalyst. $^{30}$

\section{Catalytic activity}

The photochemical reaction of $\mathrm{CO}_{2}$ reduction into formic acid $(\mathrm{HCOOH})$ and formaldehyde $(\mathrm{HCHO})$ under atmospheric pressure was carried out in the presence of heterogeneous PCA-TOL
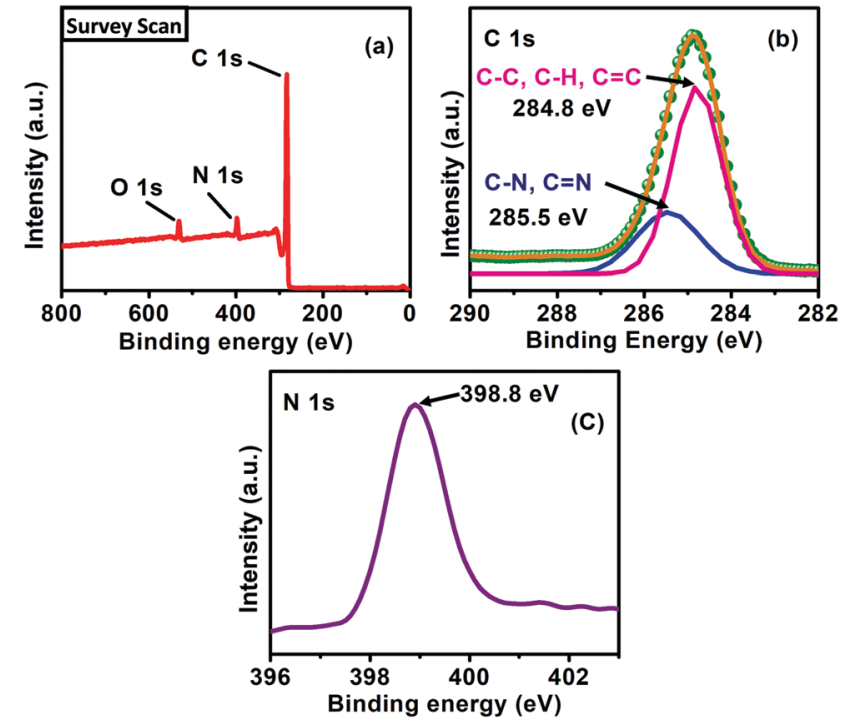

Fig. 8 (a) XPS survey scan, XPS curve of (b) $C$ 1s and (c) N1s for PCA-TOL POP. 
POP (5 mg), nickel chloride $\left(\mathrm{NiCl}_{2}, 5 \mathrm{mg}\right)$ co-catalyst and triethanolamine (TEOA, $1 \mathrm{mmol}$ ) as a sacrificial electron donor in acetonitrile $\left(\mathrm{CH}_{3} \mathrm{CN}, 5 \mathrm{~mL}\right)$ solvent at room temperature for $6 \mathrm{~h}$. The proposed reaction is shown in Fig. S1 (ESI $\dagger$ ). The reaction mixture was irradiated using $445 \mathrm{~nm}$ blue LED light under incessant stirring. At the end of this reaction, the respective yield of both the products was measured from the calibration plots (Fig. S2 and S3, ESI $\dagger$ ) using a UV-Visible spectrophotometer and PCA-TOL POP was filtered and the filtrate portion was analyzed using ${ }^{1} \mathrm{H}$ NMR and ${ }^{13} \mathrm{C}$ NMR spectroscopy (Fig. S4 and S5, ESI $\dagger$ ), which validates the generation of formic acid ( $\mathrm{HCOOH}$ ) and formaldehyde (HCHO). A range of conditions for our recent photochemical work were verified and the outcomes are discussed briefly in Tables 1 and 2 .

Irradiation of the solution containing PCA-TOL POP (5 mg) as a photocatalyst, nickel chloride $\left(\mathrm{NiCl}_{2}, 5 \mathrm{mg}\right)$, TEOA $(1 \mathrm{mmol})$ and acetonitrile as the solvent with $445 \mathrm{~nm}\left(12 \mathrm{~W} \mathrm{~cm}^{-2}\right)$ under 1 atm $\mathrm{CO}_{2}$ pressure for $6 \mathrm{~h}$ at room temperature produced formic acid with 355 TON as a major product (Table 1, entry 6) along with 47 TON formaldehyde as the minor product (Table 2, entry 6). The analysis of UV-DRS suggests that the POP catalyst exhibited outstanding absorbance for the complete region of visible light, and for this reason this POP catalyst is selectively excited in the presence of visible light which acts as an energy source. It is worth noting that the reaction proceeds even under sunlight and performs well for the generation of formic acid with 338 TON (Table 1, entry 8) and formaldehyde with 10 TON (Table 2, entry 8). The production of formic acid with 321 TON (Table 1, entry 7) and formaldehyde with 13 TON (Table 2, entry 7) was also observed when this reaction was carried out under irradiation of white

Table 1 Optimization table for the reduction of $\mathrm{CO}_{2}$ via photochemical reaction into formic acid $(\mathrm{HCOOH})$

\begin{tabular}{lllllll}
\hline S. & $\begin{array}{l}\text { PCA- } \\
\text { no. } \\
(\mathrm{mg})\end{array}$ & $\begin{array}{l}\text { Co- } \\
\text { Cat } \\
(\mathrm{mg})\end{array}$ & $\begin{array}{l}\text { Light } \\
\text { source }\end{array}$ & $\begin{array}{l}\text { Temp. } \\
\left({ }^{\circ} \mathrm{C}\right)\end{array}$ & $\begin{array}{l}\text { Yield of }_{\mathrm{HCOOH}}{ }^{a} \\
(\mathrm{~mol})\end{array}$ & $\begin{array}{l}\text { TON of } \\
\mathrm{HCOOH}^{a}\end{array}$ \\
\hline 1 & 5 & - & - & 60 & 0 & 0 \\
2 & - & 5 & - & 60 & 0 & 0 \\
3 & 5 & 5 & - & 60 & 0 & 0 \\
4 & 5 & 5 & - & 40 & 0 & 0 \\
5 & 5 & 5 & - & 50 & 0 & 0 \\
6 & 5 & 5 & $445 \mathrm{~nm}$ & $\mathrm{RT}$ & 0.0137 & 355 \\
7 & 5 & 5 & White & RT & 0.0124 & 321 \\
& & & LED & & & \\
8 & 5 & 5 & Sunlight & RT & 0.013 & 338 \\
$9^{b}$ & 5 & 5 & $445 \mathrm{~nm}$ & $\mathrm{RT}$ & 0 & 0 \\
$10^{c}$ & 5 & - & $445 \mathrm{~nm}$ & $\mathrm{RT}$ & 0 & 0 \\
11 & - & 5 & $445 \mathrm{~nm}$ & $\mathrm{RT}$ & 0 & 0 \\
12 & 5 & 5 & - & RT & 0 & 0 \\
$13^{d}$ & 5 & 5 & $445 \mathrm{~nm}$ & $\mathrm{RT}$ & 0 & 0
\end{tabular}

Reaction conditions unless otherwise noted: catalyst $(5 \mathrm{mg}), \mathrm{NiCl}_{2}$ (5 mg), acetonitrile $(5 \mathrm{~mL})$, TEOA $(1 \mathrm{mmol})$, room temperature, pressure $(1 \mathrm{~atm})$, time $(6 \mathrm{~h})$, and $\mathrm{CO}_{2}$ balloon. ${ }^{a}$ Determined from the calibration curve (the concentration of $\mathrm{HCOOH}$ is known) obtained using a UV-Visible spectrometer. ${ }^{b}$ Irradiation under an open atmosphere for 6 hours. ${ }^{c}$ The reaction was completed in 10 hours. ${ }^{d}$ The reaction proceeded without any sacrificial electron donor.
Table 2 Optimization table for the reduction of $\mathrm{CO}_{2}$ via photochemical reaction into formaldehyde $(\mathrm{HCHO})$

\begin{tabular}{|c|c|c|c|c|c|c|}
\hline $\begin{array}{l}\text { S. } \\
\text { no. }\end{array}$ & $\begin{array}{l}\text { PCA- } \\
\text { TOL } \\
\text { (mg) }\end{array}$ & $\begin{array}{l}\text { Co- } \\
\text { Cat } \\
(\mathrm{mg})\end{array}$ & $\begin{array}{l}\text { Light } \\
\text { source }\end{array}$ & $\begin{array}{l}\text { Temp. } \\
\left({ }^{\circ} \mathrm{C}\right)\end{array}$ & $\begin{array}{l}\text { Yield of } \\
\mathrm{HCHO}^{a} \\
(\mathrm{~mol})\end{array}$ & $\begin{array}{l}\text { TON of } \\
\text { HCHO }^{a}\end{array}$ \\
\hline 1 & 5 & - & - & 60 & 0 & 0 \\
\hline 2 & - & 5 & - & 60 & 0 & 0 \\
\hline 3 & 5 & 5 & - & 60 & 0 & 0 \\
\hline 4 & 5 & 5 & - & 40 & 0 & 0 \\
\hline 5 & 5 & 5 & - & 50 & 0 & 0 \\
\hline 6 & 5 & 5 & $445 \mathrm{~nm}$ & RT & 0.0018 & 47 \\
\hline 7 & 5 & 5 & $\begin{array}{l}\text { White } \\
\text { LED }\end{array}$ & $\mathrm{RT}$ & 0.0005 & 13 \\
\hline 8 & 5 & 5 & Sunlight & $\mathrm{RT}$ & 0.0004 & 10 \\
\hline $9^{b}$ & 5 & 5 & $445 \mathrm{~nm}$ & $\mathrm{RT}$ & 0 & 0 \\
\hline $10^{c}$ & 5 & - & $445 \mathrm{~nm}$ & $\mathrm{RT}$ & 0 & 0 \\
\hline 11 & - & 5 & $445 \mathrm{~nm}$ & $\mathrm{RT}$ & 0 & 0 \\
\hline 12 & 5 & 5 & - & RT & 0 & 0 \\
\hline $13^{d}$ & 5 & 5 & $445 \mathrm{~nm}$ & RT & 0 & 0 \\
\hline
\end{tabular}

Reaction conditions unless otherwise noted: catalyst $(5 \mathrm{mg}), \mathrm{NiCl}_{2}$ $(5 \mathrm{mg})$, acetonitrile $(5 \mathrm{~mL})$, TEOA $(1 \mathrm{mmol})$, room temperature, pressure ( $1 \mathrm{~atm})$, time $(6 \mathrm{~h})$, and $\mathrm{CO}_{2}$ balloon. ${ }^{a}$ Determined from the calibration curve (the concentration of $\mathrm{HCOOH}$ is known) obtained using a UV-Visible spectrometer. ${ }^{b}$ Irradiation under an open atmosphere for 6 hours. ${ }^{c}$ Reaction was completed in 10 hours. ${ }^{d}$ Reaction proceeded without any sacrificial electron donor.

LED light. In the nonexistence of light at room temperature (Table 1, entry 12 and Table 2, entry 12) even at high temperatures (Table 1 , entry 3 and Table 2 , entry 3 ) no reaction could be started, which ensures light dependence on $\mathrm{CO}_{2}$ reduction by the POP component. In a dark environment, at high temperatures up to $60{ }^{\circ} \mathrm{C}$ (entry 1-5 in Tables 1 and 2), the reaction did not proceed which indicates that these are not thermal transformations. It is significant to note that without the POP photocatalyst, irradiation of the $\mathrm{NiCl}_{2}$ co-catalyst with a sacrificial electron source and $\mathrm{CO}_{2}$ in the $\mathrm{CH}_{3} \mathrm{CN}$ solvent could not develop any product (entry 2 in Table 1 and entry 2 in Table 2). Correspondingly, with the excitation of the POP material in the range of visible light along with a co-catalyst in the absence of TEOA (sacrificial electron source), the reaction could not proceed (entry 13 in Table 1 and entry 13 in Table 2). The reaction mainly occurred following the three steps: (i) photoexcitation of POP, (ii) transfer of electron to the co-catalyst $\mathrm{NiCl}_{2}$ and (iii) regeneration of POP by a sacrificial electron source, TEOA.

The intensity of light was varied from $3 \mathrm{~W}$ to $17 \mathrm{~W}$ using the optimized photocatalytic system for the $\mathrm{CO}_{2}$ reduction to $\mathrm{HCOOH}$ and $\mathrm{HCHO}$ (Fig. 9). From Fig. 9, it is evident that with increasing light intensity the obtained yields of the products with $\mathrm{CO}_{2}$ reduction increase. At the beginning with increasing light intensity the $\mathrm{HCOOH}$ product formation increases rapidly but after a certain amount of light intensity the increment rate slowed down, which could be due the fact that with increasing photon flux the $4 \mathrm{e}^{-}$transfer reaction was facilitated rather than the $2 \mathrm{e}^{-}$transfer, therefore consequently $\mathrm{HCOOH}$ converted to $\mathrm{HCHO}$ through a further reduction process. This demonstrates that the formation of products depends on the quantity of photon-flux on the reaction mixture. 

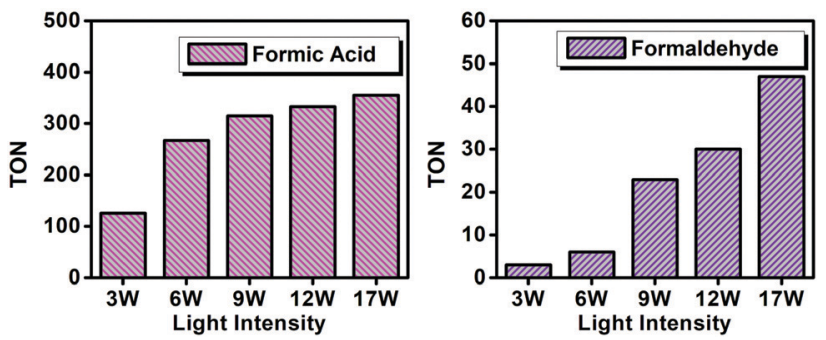

Fig. 9 Effect of light intensity on the yield of photocatalytic $\mathrm{CO}_{2}$ reduction products catalyzed by PCA-TOL POP.

Fig. 10 suggests that the increment of the $\mathrm{HCOOH}$ and HCHO production was observed with increasing irradiation time until $6 \mathrm{~h}$. Furthermore, the reaction mixture was irradiated up to $48 \mathrm{~h}$ without any enhancement of yield. Hence, it is concluded that the completion of reaction time was noticed after irradiating the reaction mixture for $6 \mathrm{~h}$. It is interesting to note that after $6 \mathrm{~h}$ of irradiation, the formation of both the products slowed down and the amount of yield decreases.

The formation of $\mathrm{HCOOH}$ and $\mathrm{HCHO}$ with $\mathrm{CO}_{2}$ reduction using the POP catalyst is solely linked to the light as verified by investigating the production of products while controlling the light and dark environments at 30 min breaks (Fig. 11). The product formation increases during irradiation of light; however, in the progression of a $3 \mathrm{~h}$ experiment it remains nearly constant in the absence of light.

\section{Plausible mechanism}

The probable formation mechanism of $\mathrm{HCOOH}$ and $\mathrm{HCHO}$ is depicted in Fig. 12. Here, PCA-TOL POP performs as a potentially dynamic photocatalyst for avisible-light driven reaction. Besides the textural properties, the morphology (sheet-like) of the synthesized POP material offers additional geometrical sites which provide many surface-active sites and assist heterogeneous catalysis. Upon irradiation with visible light, PCA-TOL POP becomes a photo-excited state (PCA-TOL POP*) and reduces $\mathrm{H}^{+}$into $\mathrm{H}$. After that, the catalytic cycle proceeds through an oxidative quenching process ${ }^{31}$ followed by formation of a cationic radical which remains in the ground state by acquiring a single electron from a sacrificial electron donor (TEOA), while PCA-TOL POP regenerates itself and is available for the next cycle. Meanwhile, the metal cocatalyst ( $\mathrm{NiCl} 2)$ with a lower Fermi level can readily trap electrons and it possesses effective reduction sites within the pores that significantly aid reduction
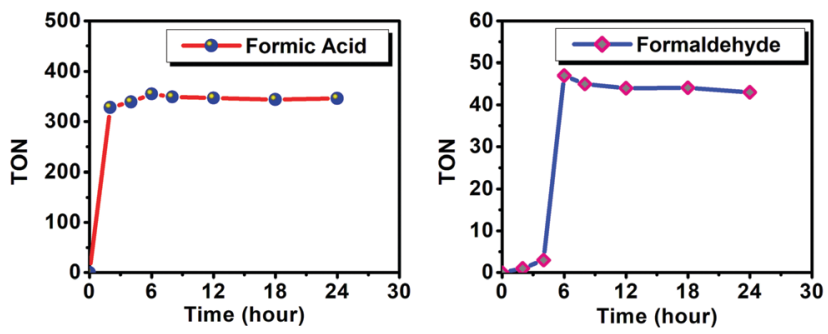

Fig. 10 Formation of formic acid and formaldehyde with time upon irradiation.
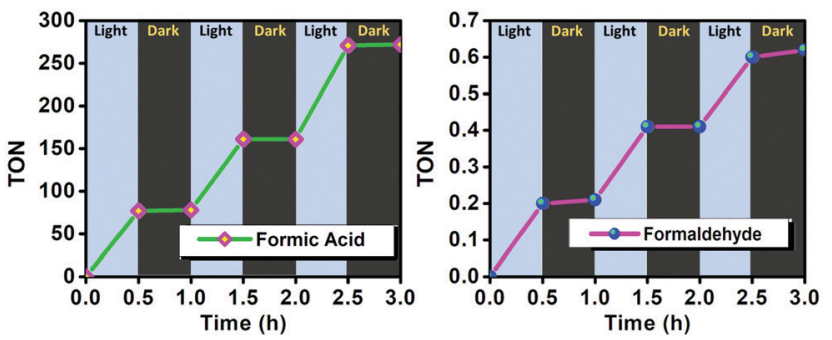

Fig. 11 TON of formic acid formed with respect to time while modulating between light and dark under optimum reaction conditions.

reactions. The photocatalytic activity of the POP catalyst is boosted by the partial captivity of the metal active sites within the pores of the photocatalyst, which create strong interfacial electronic interactions between the POP photocatalyst and $\mathrm{NiCl}_{2}$ cocatalyst, enhancing the interfacial electron transfer from POP to $\mathrm{NiCl}_{2}$. When $\mathrm{Ni}(\mathrm{I})$ oxidizes itself into $\mathrm{Ni}(\mathrm{II}), \mathrm{CO}_{2}$ gets reduced to $\mathrm{HCOOH}$ by two electron charge transfer and $\mathrm{HCHO}$ by four electron charge transfer using TEOA as the proton source.

Comparison for photocatalytic potentiality of our POP catalyst in $\mathrm{CO}_{2}$ reduction reactions with other published catalyst schemes

The comparison of our recent work using a PCA-TOL POP compound with other reported catalytic processes for the
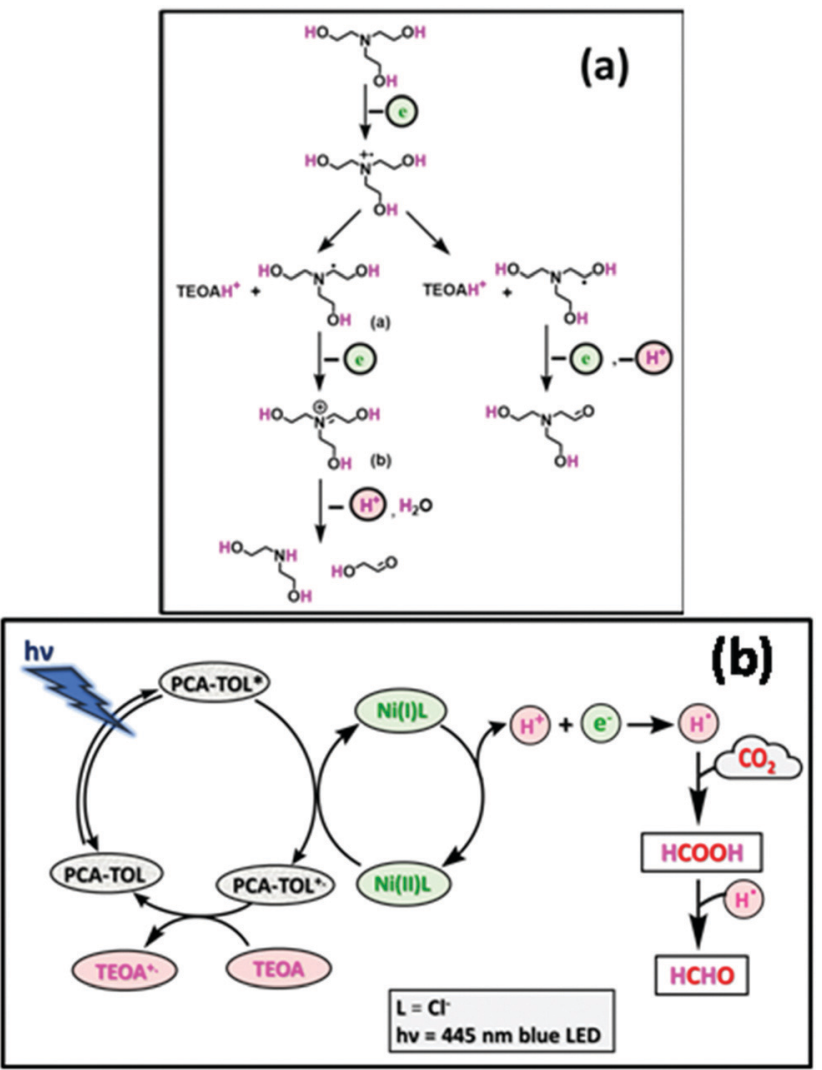

Fig. 12 Proposed (a) degradation pathway of TEOA and (b) plausible mechanism for the photo-induced $\mathrm{CO} 2$ reduction reaction into $\mathrm{HCOOH}$ and $\mathrm{HCHO}$ by the PCA-TOL POP catalyst. 
Table 3 Comparison table for $\mathrm{CO}_{2}$ reduction reactions using PCA-TOL POP with other reported catalysts

\begin{tabular}{|c|c|c|c|c|}
\hline Catalyst & Reaction conditions & $\begin{array}{l}\text { Yield of } \\
\text { HCOOH } \\
(\mathrm{mol})\end{array}$ & $\begin{array}{l}\text { Yield of } \\
\text { HCHO } \\
\text { (mol) }\end{array}$ & Ref. \\
\hline $\begin{array}{l}\text { Giant polyoxome- } \\
\text { alate }\left\{\mathrm{Mo}_{368}\right\}\end{array}$ & Catalyst (0.0003 mmol), $373 \mathrm{~nm}$ UV-light & 0.0083 & $\begin{array}{l}3.7 \times \\
10^{-5}\end{array}$ & 34 \\
\hline TFPG-DAAQ COF & $\begin{array}{l}\text { Photocatalyst }(10 \mathrm{mg}) \text {, Co-catalyst }\left(\mathrm{Co}(\mathrm{dmg})_{2}\right), 445 \mathrm{~nm} \text { blue LED } \\
\text { light, } \mathrm{CO}_{2}(1 \mathrm{~atm}), \text { room temperature }\end{array}$ & 0.0108 & - & 31 \\
\hline $\mathrm{SnO}_{2}$ nanoparticles & Catalyst (10 mg), white LED light, $\mathrm{CO}_{2}(1 \mathrm{~atm})$, room temperature & 0.0076 & - & 26 \\
\hline
\end{tabular}

production of $\mathrm{HCOOH}$ and $\mathrm{HCHO}$ is summarized in Table 3. Our catalyst demonstrated the excellent yields of the outcome with economically efficacious green reaction conditions compared to the other reported catalysts. According to some previously reported studies, ${ }^{32,33}$ sheet-like POPs are advantageous for heterogeneous catalysis rather than bulk POPs. Bulk POP formed by stacked layers creates an obstacle for ion diffusion and for reaching the active sites, and the defects of POPs and boundaries between particles confine the transportation of electrons and ions which lead to an increased mass transport resistance and inherent low conductivity of bulk POPs, consequently limiting their applications. On the other hand, the sheet-like POPs with a thickness of single- or few-atom layers having unique chemical, physical, electronic, and optical properties can minimize the transport length for the ions to reach the active sites, and provide sufficient electron conduction pathways.

\section{Recyclability of the catalyst}

To verify the recyclability of the PCA-TOL POP catalyst, the catalyst was collected after the completion of each reaction cycle using a centrifugation method followed by several washing steps with ethanol followed by drying in an oven for the subsequent run. Fig. 13 shows that negligible changes were noticed in the yields of both products (formic acid and formaldehyde) after reprocessing the POP up to 5 reaction cycles. The TON values of the products for different cycles are shown in Table 4. As shown in the FTIR spectra of the recycled catalyst in Fig. S6, the recycled catalyst retains all the peaks of the original PCA-TOL POP after recycling, i.e. the structure of the catalyst remains unchanged. Furthermore, the morphology of the recycled catalyst also retained itself which was confirmed by the FESEM analysis of the recycled catalyst as shown in Fig. S7.
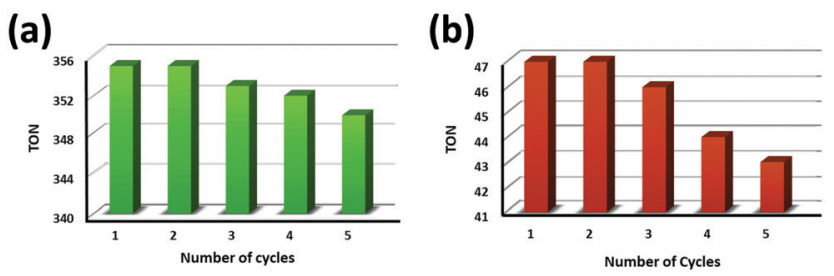

Fig. 13 Recyclable potentiality of the PCA-TOL POP photocatalyst for (a) formic acid and (b) formaldehyde production.
Table 4 Chart of catalytic activity for the recycled PCA-TOL POP photocatalyst

\begin{tabular}{llll}
\hline Entry & No. of cycles & TON $^{a}$ of formic acid & TON $^{a}$ of formaldehyde \\
\hline 1 & 1st & 355 & 47 \\
2 & 2nd & 355 & 47 \\
3 & 3rd & 353 & 45 \\
4 & 4th & 352 & 44 \\
5 & 5th & 350 & 42
\end{tabular}

Reaction conditions unless otherwise noted: catalyst $(5 \mathrm{mg}), \mathrm{NiCl}_{2}$ $(5 \mathrm{mg})$, acetonitrile $(5 \mathrm{~mL})$, TEOA $(1 \mathrm{mmol})$, room temperature, pressure (1 atm), time $(6 \mathrm{~h})$, and $\mathrm{CO}_{2}$ balloon. ${ }^{a}$ The yield of each product was ascertained from a calibration plot obtained using a UV-vis spectrometer.

These observations help us to predict that the prepared PCA-TOL POP material is heterogeneous in nature as well as stable, recyclable and effective for photocatalytic $\mathrm{CO}_{2}$ reduction reaction under environmentally green reaction conditions. This investigation suggests the economic significance and scalability of the POP as an efficient photocatalyst for the reaction of $\mathrm{CO}_{2}$ reduction.

\section{Conclusion}

A sheet-like PCA-TOL POP photocatalyst is fabricated through a facile solvothermal process. The formed POP material serves as a potential photocatalyst along with $\mathrm{NiCl}_{2}$ as the co-catalyst to reduce $\mathrm{CO}_{2}$ under visible light (blue LED) irradiation and atmospheric pressure in a green route to generate formic acid and formaldehyde with an excellent TON value. The catalytic reduction does not proceed without a catalyst, co-catalyst or even light and heat which is confirmed by control reactions and therefore the yield of the reduced products can effortlessly be monitored by tuning the light intensity. Furthermore, the POP photocatalyst additionally provides facile recovery and reusability for several reaction cycles without considerable catalyst deactivation.

\section{Conflicts of interest}

There are no conflicts to declare. 


\section{Acknowledgements}

SMI thankfully acknowledges the Department of Science and Technology DST-SERB (project reference no. CRG/2020/000 244), New Delhi, Govt. of India and Council of Scientific and Industrial and Research, CSIR (project reference no 02(0453)21/ EMR-II), New Delhi, Govt. of India for providing financial support. I. H. Chowdhury is thankful to CSIR, India (File no. 09/106(0181)/2019-EMR-I) for her fellowship. S. Das is thankful to SVMCM Fellowship, Govt. of West Bengal, India. SMI is thankful to University of Kalyani for providing support under the PURSE and PRG program. We acknowledge the DST for providing a grant to the Department of Chemistry by FIST, PURSE grant.

\section{Notes and references}

1 https://gml.noaa.gov/cegg/trends/mlo.html.

2 (a) Q. Liu, L. Wu, R. Jackstell and M. Beller, Nat. Commun., 2015, 6, 1-5; (b) M. R. Kember, A. Buchard and C. K. Williams, Chem. Commun., 2011, 47, 141-163.

3 (a) A. J. Kamphuis, F. Picchioni and P. P. Pescarmona, Green Chem., 2019, 21, 406-448; (b) I. H. Chowdhury, A. H. Chowdhury, P. Sarkar and S. M. Islam, ChemNanoMat, 2021, 7, 580-591; (c) A. H. Chowdhury, I. H. Chowdhury, S. Biswas and S. M. Islam, Mol. Catal., 2020, 493, 111050; (d) A. H. Chowdhury, I. H. Chowdhury and S. M. Islam, Ind. Eng. Chem. Res., 2019, 58, 11779-11786; (e) S. Ghosh, R. A. Molla, U. Kayal, A. Bhaumik and S. M. Islam, Dalton Trans., 2019, 48, 4657-4666; $(f)$ S. M. Islam, D. Mal, B. K. Palit and C. R. Saha, J. Mol. Catal. A: Chem., 1999, 142, 169-181; $(g)$ N. Haque, S. Biswas, P. Basu, I. H. Biswas, R. Khatun, A. Khan and S. M. Islam, New J. Chem., 2020, 44, 15446-15458; (h) A. Sahoo, A. H. Chowdhury, P. Singha, A. Banerjee, S. M. Islam and T. Bala, Mol. Catal., 2020, 493, 111070.

4 (a) B. Yu and L. N. He, ChemSusChem, 2015, 8, 52-62; (b) H. R. Li and L. N. He, Organometallics, 2019, 39, 1461-1475; (c) M. Y. Wang, Y. Cao, X. Liu, N. Wang, L. N. He and S. H. Li, Green Chem., 2017, 19, 1240-1244; (d) L. Sun, J. H. Ye, W. J. Zhou, X. Zeng and D. G. Yu, Org. Lett., 2018, 20, 3049-3052; (e) S. S. Islam, P. Bhanja, K. Ghosh, R. A. Molla, N. Yasmin, D. Das and S. M. Islam, ChemistrySelect, 2017, 2, 10595-10602; $(f)$ N. Haque, S. Biswas, S. Ghosh, A. H. Chowdhury, A. Khan and S. M. Islam, ACS Appl. Nano Mater., 2021, 4, 7663-7674.

5 (a) Y. Chen and T. Mu, Green Chem., 2019, 21, 2544-2574;

(b) P. Sarkar, A. H. Chowdhury, S. Riyajuddin, S. Biswas, K. Ghosh and S. M. Islam, New J. Chem., 2020, 44, 744-752; (c) P. Chakrabortty, A. Das, A. H. Chowdhury, S. Ghosh, A. Khan and S. M. Islam, New J. Chem., 2021, 45, 4738-4745; (d) P. Sarkar, A. H. Chowdhury, S. Biswas, A. Khan and S. M. Islam, Mater. Today Chem., 2021, 21, 100509; (e) S. Biswas, R. Khatun, M. Sengupta and S. M. Islam, Mol. Catal., 2018, 452, 129-137; $(f)$ S. Roy, B. Banerjee, A. Bhaumik and S. M. Islam, RSC Adv., 2016, 6,
31153-31160; $(g)$ S. Ghosh, P. Bhanja, R. A. Molla, R. Khatun and S. M. Islam, ChemistrySelect, 2017, 2, 2159-2165.

6 (a) S. Wang and C. Xi, Chem. Soc. Rev., 2019, 48, 382-404; (b) R. A. Molla, M. A. Iqubal, K. Ghosh and S. M. Islam, Green Chem., 2016, 18, 4649-4656; (c) R. Khatun, S. Biswas, I. H. Biswas, S. Riyajuddin, N. Haque and K. Ghosh, J. CO2 Utiliz., 2020, 40, 101180; (d) R. Khatun, P. Bhanja, R. A. Molla, S. Ghosh, A. Bhaumik and S. M. Islam, Mol. Catal., 2017, 434, 25-31; (e) S. Biswas, R. Khatun, M. Dolai, I. H. Biswas, N. Haque, M. Sengupta and S. M. Islam, New J. Chem., 2020, 44, 141-151; $(f)$ I. H. Biswas, S. Biswas, M. S. Islam, S. Riyajuddin, P. Sarkar and K. Ghosh, New J. Chem., 2019, 43, 14643-14652; $(g)$ S. Ghosh, A. Ghosh, S. Riyajuddin, S. Sarkar, A. H. Chowdhury and K. Ghosh, Chem. Cat. Chem., 2020, 12, 1055-1067; (h) S. Sarkar, S. Ghosh, J. Mondal and S. M. Islam, Chem. Commun., 2020, 56, 12202-12205; (i) T. K. Dey, P. Bhanja, P. Basu, A. Ghosh and S. M. Islam, ChemistrySelect, 2019, 4, 14315-14328; $(j)$ S. Ghosh, A. Ghosh, S. Biswas, M. Sengupta, D. Roy and S. M. Islam, ChemistrySelect, 2019, 4, 3961-3972; ( $k$ ) S. S. Islam, S. Biswas, R. Ali Molla, N. Yasmin and S. M. Islam, ChemNanoMat, 2020, 6, 1386-1397; (l) P. Basu, T. K. Dey, S. Riyajuddin, S. Biswas, K. Ghosh and S. M. Islam, New J. Chem., 2020, 44, 12680-12691.

7 (a) B. Grignard, S. Gennen, C. Jérôme, A. W. Kleij and C. Detrembleur, Chem. Soc. Rev., 2019, 48, 4466-4514; (b) R. Khatun, S. Biswas, S. Islam, I. H. Biswas, S. Riyajuddin, K. Ghosh and S. M. Islam, ChemCatChem, 2019, 11, 1303-1312; (c) M. Sengupta, A. Bag, S. Ghosh, P. Mondal, A. Bordoloi and S. M. Islam, J. CO2 Utiliz., 2019, 34, 533-542; (d) A. H. Chowdhury, S. Ghosh and S. M. Islam, New J. Chem., 2018, 42, 14194-14202; (e) R. Khatun, P. Bhanja, P. Mondal, A. Bhaumik, D. Das and S. M. Islam, New J. Chem., 2017, 41, 12937-12946; $(f)$ A. H. Chowdhury, U. Kayal, I. H. Chowdhury, S. Ghosh and S. M. Islam, ChemistrySelect, 2019, 4, 1069-1077; $(g)$ S. Ghosh, P. Bhanja, N. Salam, R. Khatun, A. Bhaumik and S. M. Islam, Catal. Today, 2018, 309, 253-262.

8 (a) M. Cokoja, C. Bruckmeier, B. Rieger, W. A. Herrmann and F. E. Kühn, Angew. Chem., Int. Ed., 2011, 50, 8510-8537; (b) I. Omae, Coord. Chem. Rev., 2012, 256, 1384-1405; (c) S. Ghosh, S. Riyajuddin, S. Sarkar, K. Ghosh and S. M. Islam, ChemNanoMat, 2020, 6, 160-172; (d) S. Ghosh, P. Mondal, D. Das, K. Tuhina and S. M. Islam, J. Organomet. Chem., 2018, 866, 1-12; (e) N. Salam, P. Paul, S. Ghosh, U. Mandi, A. Khan, S. M. Alam, D. Das and S. M. Islam, New J. Chem., 2020, 44, 5448-5456; $(f)$ S. S. Islam, N. Salam, R. A. Molla, S. Riyajuddin, N. Yasmin, D. Das and K. Ghosh, Mol. Catal., 2019, 477, 110541; (g) R. K. Mondal, S. Riyajuddin, A. Ghosh, S. Ghosh, K. Ghosh and S. M. Islam, J. Organomet. Chem., 2019, 880, 322-332; (h) S. Biswas, D. Roy, S. Ghosh and S. M. Islam, J. Organomet. Chem., 2019, 898, 120877; (i) A. Das, R. K. Mondal, P. Chakrabortty, S. Riyajuddin and A. H. Chowdhury, Mol. Catal., 2021, 499, 111253. 
9 (a) X. He, L. Q. Qiu, W. J. Wang, K. H. Chen and L. N. He, Green Chem., 2020, 22, 7301-7320; (b) Z. J. Wang, H. Song, H. Liu and J. Ye, Angew. Chem., Int. Ed., 2020, 59, 8016-8035.

10 I. H. Chowdhury, A. H. Chowdhury, A. Das, A. Khan and S. M. Islam, New J. Chem., 2020, 44, 11720-11726.

11 Z. Li, J. Chu, D. Meng, Y. Wen, X. Xing, H. Miao, M. Hu, C. Yu, Z. Wei, Y. Yang and Y. Li, ACS Catal., 2019, 9, 8659-8668.

12 P. Bhanja, A. Modak and A. Bhaumik, ChemCatChem, 2019, 11, 244-257.

13 S. Das, P. Heasman, T. Ben and S. Qiu, Chem. Rev., 2017, 117, 1515-1563.

14 T. X. Wang, H. P. Liang, D. A. Anito, X. Ding and B. H. Han, J. Mater. Chem. A, 2020, 8, 7003-7034.

15 M. Du, A. M. Agrawal, S. Chakraborty, S. J. Garibay, R. Limvorapitux, B. Choi, S. T. Madrahimov and S. T. Nguyen, ACS Sustainable Chem. Eng., 2019, 7, 8126-8135.

16 W. Liu, C. Wang, L. Zhang, H. Pan, W. Liu, J. Chen, D. Yang, Y. Xiang, K. Wang, J. Jiang and X. Yao, J. Mater. Chem. A, 2019, 7, 3112-3119.

17 C. Zhao, Z. Chen, R. Shi, X. Yang and T. Zhang, Adv. Mater., 2020, 32, 1907296.

$18 \mathrm{Z} . \mathrm{Li}$ and Y. W. Yang, J. Mater. Chem. B, 2017, 5, 9278-9290.

19 P. Kaur, J. T. Hupp and S. T. Nguyen, ACS Catal., 2011, 1, 819-835.

20 (a) W. Zhang, B. Aguila and S. Ma, J. Mater. Chem. A, 2017, 5, 8795-8824; (b) X. Zou, H. Ren and G. Zhu, Chem. Commun., 2013, 49, 3925-3936.
21 Q. Sun, Z. Dai, X. Meng, L. Wang and F. S. Xiao, ACS Catal., 2015, 5, 4556-4567.

22 T. Zhang, G. Xing, W. Chen and L. Chen, Mater. Chem. Front., 2020, 4, 332-353.

23 B. Aguila, Q. Sun, J. A. Perman, L. D. Earl, C. W. Abney, R. Elzein, R. Schlaf and S. Ma, Adv. Mater., 2017, 29, 1700665.

24 Q. Sun, Z. Dai, X. Meng, L. Wang and F. S. Xiao, ACS Catal., 2015, 5, 4556-4567.

25 L. E. Heim, H. Konnerth and M. H. Prechtl, Green Chem., 2017, 19, 2347-2355.

26 A. H. Chowdhury, A. Das, S. Riyajuddin, K. Ghosh and S. M. Islam, Catal. Sci. Tech., 2019, 9, 6566-6569.

27 H. Wu, J. Song, C. Xie, Y. Hu and B. Han, Green Chem., 2018, 20, 1765-1769.

28 L. Wang, J. Liu, H. Wang, H. Cheng, X. Wu, Q. Zhang and H. Xu, Sci. Bull., 2021, 66, 265-274.

29 J. F. Moulder, Phys. Electron., 1995, 230-232.

30 Z. Xin, Y. Qiuhua and C. U. I. Jinjin, J. Rare Earths, 2008, 26, 511-514.

31 P. Sarkar, S. Riyajuddin, A. Das, A. H. Chowdhury, K. Ghosh and S. M. Islam, Mol. Catal., 2020, 484, 110730.

32 J. Li, X. Jing, Q. Li, S. Li, X. Gao, X. Feng and B. Wang, Chem. Soc. Rev., 2020, 49, 3565-3604.

33 H. Wang, Z. Zeng, P. Xu, L. Li, G. Zeng, R. Xiao, Z. Tang, D. Huang, L. Tang, C. Laiand and D. Jiang, Chem. Soc. Rev., 2019, 48, 488-516.

34 S. Das, T. Balaraju, S. Barman, S. S. Sreejith, R. Pochamoni and S. Roy, Front. Chem., 2018, 6, 514. 